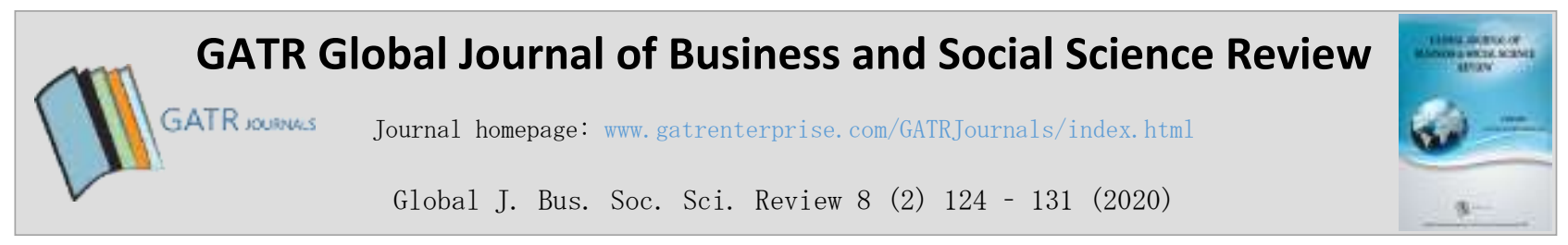

\title{
Collaborative Governance Approaches in Dealing with Financial Deficits in the JKN-KIS Program in Indonesia
}

\author{
Miptahul Janah ${ }^{1}$, Amy Y. Sri Rahayu² \\ ${ }^{1}$ Coordinating Ministry for Human Development and Cultural Affairs Republic of Indonesia, Indonesia \\ ${ }^{2}$ Faculty of Administrative Science, University of Indonesia (FIA-UI), 16424, Depok, Indonesia
}

\begin{abstract}
Objective - The imbalance in income and expenditure in the JKN-KIS program clearly illustrates the main causes of its financial balance deficit. The government has implemented many top-down programs to overcome this issue, but these efforts have not yet shown any satisfying outcomes. The collaborative efforts in dealing with budget deficit problems in the JKN-KIS program have been carried out by many actors. The extant literature suggests it should be noted that the components are comprehensive and appropriately used in answering problems. This study consists of a theoretical discussion focusing on the potentials and challenges of bottom-up collaborative governance concept as well as a practical example of how this concept works in dealing with financial deficits in the National Health Insurance (JKN) program in Indonesia.

Methodology/Technique - This study aims to explain the tendency of collaborative governance approach used. This study is conducted using a post-positivism approach with qualitative and quantitative data analysis using 13 state and non-state institutions for the period of the JKN from 2014 to 2018.

Finding \& Novelty - The results of the study show that there is no dominant tendency in each existing model. However, there are a "red thread" between collaborative governance models formulated. The results suggest that a bottom-up approach emerges as a critique to the old scheme of top-down approach in which the participation of the citizens or NGOs are not proportionally given. This finding implies that in adopting the bottom-up collaborative governance concept there are significant challenges for the collaborative governance approach in the future.
\end{abstract}

Type of Paper: Review

JEL Classification: I13, I18.

Keywords: Financial Deficit; Health Insurance; Collaborative Governance; Bottom-up.

Reference to this paper should be made as follows: Janah, M; Rahayu, A.Y.S. (2020). Collaborative Governance Approach in dealing with financial deficits on JKN-KIS Program in Indonesia, Global J. Bus. Soc. Sci. Review, 8(2): 124 - 131. https://doi.org/10.35609/gjbssr.2020.8.2(6)

\section{Introduction}

The Indonesian government has established through Law Number 40 of 2004 concerning the National Social Security System (SJSN) which is a manifestation of Article 34 paragraph 2 of the 1945 Constitution

\footnotetext{
* Paper Info: Revised: March 13, 2020

Accepted: June 2, 2020

* Corresponding author: Miptahul Janah

E-mail: miftahusein5@gmail.com

Affiliation: Coordinating Ministry for Human Development and Cultural Affairs Republic of Indonesia, Indonesia
} 
concerning guarantees of social justice for all Indonesian people. As a manifestation, through the National Social Security System Law, in 2014 a National Health Insurance (JKN) program was formed which was held by a public legal entity known as the Health Social Security Organizing Agency (BPJS).

The Indonesian government has established through Law Number 40 of 2004 concerning the National Social Security System (SJSN) which is a manifestation of Article 34 paragraph 2 of the 1945 Constitution concerning guarantees of social justice for all Indonesian people. As a manifestation, through the National Social Security System Law, in 2014 a National Health Insurance (JKN) program was formed which was held by a public legal entity known as the Health Social Security Organizing Agency (BPJS).

The JKN program is an aspiration set forth in the 5th Nawacita, namely Improving the Quality of Indonesian Human Life and is one of the national strategic programs. By the end of 2018, more than $80 \%$ of Indonesia's total population of 265 million has been recorded in the Universal Health Coverage (UHC) achievement in Indonesia. However, the achievements of the UHC are not in line with the effectiveness of its financial management. One of the biggest problems faced by the BPJS at present is financial deficit. The authors found that there are 3 main causes for the slow handling of the budget deficit problem in the JKNKIS program in Indonesia. The first cause, during this time the program handling the budget deficit in the BPJS of Health still focused on partial policy options between Ministries /Institutions. Each has a handling agenda in accordance with its own perspective and glasses with the lack of a joint discussion forum formed due to the existence of sectoral egos between government institutions. The second cause is the existing effort still relies on a common top-down program (business as usual) and lack of approach that involving public interest and participation. The third cause, the lack of overall coordination between government institutions related to the JKN program and the overlapping of duties and functions and misperceptions about the limitations of the authority of each institution. In addition, there is a lack of involvement of other stakeholders in disseminating government steps to the public.

This research provides a novel aspect of governance studies existing collaborative administration, specifically on the construction of collaborative governance models in handling budget deficit in the JKNKIS Program in Indonesia. This research examines the aspect of collaborative governance through 2 concepts of collaboration. Furthermore, this research is expected to be able to answer and create collaborative governance construction models that are relevant to the problem; it can consist of formulations that have been previously formulated, mixing (Hybrid concept) from an existing formula, or can also produce construction a collaborative governance model that has never been analyzed and formulated in previous research.

The approach used in this research is post-positivism with mixed-research methods, namely qualitative and quantitative research methods. The qualitative approach is based on one participatory perspective the component is collaboration while the quantitative approach is used for answering the question of trends by testing the dimensions of both model's collaboration used. This method uses the quantification of informants' answers into numbers. This research was conducted limited to 13 institutions associated with handling deficit on JKN.

In essence, this research was conducted to illustrate how the tendency of the Collaborative Governance model is formed in the effort the government and stakeholders deal with related Joint issues budget deficit in the JKN-KIS Program organized by BPJS Health. To prove the truth of theories related to collaborative governance in problems that are raised in this study, the researchers use the theory of Collaborative Governance through a model developed by Ansell and Gash (2007) and a model developed by Emerson and Nabatchi (2015) related to the integrated framework in governance collaboration through the concept of Collaborative Governance Regime (CGR). Selection of the theory is based on the compatibility of the prerequisites in the two models above with the object of the study.

In this study, the researchers use a post-positivist approach to reduce concepts, variables, and indicators regarding governance processes and dynamics collaboration and things that influence it from the Collaborative Governance model developed in both models. The researchers try to explore and understand the meaning of what happens to a problem. Furthermore, the researchers use a deductive mindset to 
downgrade the initial theory and is associated with research results in the field. This study provides a different result from that of previous related studies on the development of the construction of collaborative governance approach related to the issue of health service programs. Moreover, a number of previous studies have failed to provide sufficient analysis of collaborative governance construction through 2 theories simultaneously. The novelty of this study compared to previous studies is that there is that it examines the construction of collaborative governance models in handling the BPJS Health budget deficit in the JKN-KIS national strategic program in Indonesia. Considering that the program is one of the national priority programs, this research will be very useful in finding construction and the right solution to the indications of problems that have not been identified.

\section{Related Literature and Hypothesis Development}

\subsection{Pattern of Governance and Collaborative Governance}

In the current era of government, unusual efforts are needed to handle different public problems. It is very important to involve stakeholders from outside of the government and bottom-up governance is needed. Donahue and Zeckhauser (2011) explain that government agencies at all levels have the opportunity to collaborate with the private sector in achieving public goals. In fact, the existence of private actors in certain cases can be an intermediary for government institutions that have conflicts of interest and authority. This step can make the resolution of public problems run more effectively. When the meaning of public government has developed, so has its scientific and practical use. George Frederickson (1999) states that the study and practice of public administration has become the study and practice of governance and that new forms of cross-border governance have developed far beyond the traditional approach to government services. The traditional pattern of governance will be obsolete along with the administrative reform movement in the global governance system. At least the current governance in Indonesia goes hand in hand with the development of a global governance system leaving the traditional pattern. Goldsmith and Eggers (2004: 7) state that:

"The traditional and hierarchical model of government does not meet the demands of this complex and rapidly changing era. A rigid bureaucratic system that operates with command and control procedures, narrow work restrictions, and an inward-looking culture and operational model is not very suitable for overcoming problems that often go beyond organizational boundaries. "

Some scholars describe this as "new government" (Salamon 2002). This new government consists of horizontal networks involving public, private, and non-profit organizations rather than just hierarchical organizations (Bingham, Nabatchi, \& O'Leary, 2005). In short, modern governance is understood to be more horizontal, more cross-border, and more collaborative.

Departing from the above conceptual arguments, collaborative governance is needed to face the changing times and to handle deficits in the JKN program. Donahue (2004) emphasizes collaboration on the added value of private sector expertise and knowledge that can be brought to address public sector issues. One example of a policy consensus initiative at Portland State University initiated the University Network for Collaborative Governance in 2008. In that case, the definition of collaborative governance includes a forum for public consultation, resolution of community problems, and multi-stakeholder dispute resolution. This has similarities to the handling problems in the current JKN program, where collaborative initiatives coming from organizations outside the government have also begun to occur. The collaborative governance regime network can be used to handle budget deficits by developing bottom-up collaboration patterns. Thus, the collaboration that should be formed in handling deficits in the JKN program can involve grassroots stakeholders in a bottom-up manner. 
$\mathrm{H}$ : Bottom-up collaboration patterns are suitable for overcoming problems that often go beyond organizational boundaries.

\subsection{Participation of Non-governmental Actors and Collaborative Governance}

The demand for the participation of non-governmental actors in public governance or management according to Emerson and Nabatchi (2015) is influenced by two major factors. First, the public issue is "Wicked Problems". Wicked problems is a term used by Rittel and Weber (1973) to describe severe problems that cannot be solved with different and conflicting information, the existence of rapid environmental changes and the increasing complexity of interdependence among existing elements. Examples of wicked problems range from education, health care, justice systems, transportation systems and other infrastructure systems. Wicked problems also include crisis issues, ranging from financial crises, industrial markets to energy crises that are in global issues such as climate change, food scarcity, human trade, and so forth. Second, as the number and complexity of public problems continue to increase, so too the context in which these problems must be solved becomes more complex.

Ongoing resources for public institutions and programs are decreasing every day, the public sector labor market is largely damaged and in trouble, the supply of non-negotiable political support for policies and programs is decreasing rapidly at all levels of government and throughout the world (Nabatchi, Goerdel \& Peffer 2011, i29). In this context, an integrated collaborative framework in handling governance issues in Indonesia is needed, more specifically in this research which is related to the problem of financial management of the National Health Insurance program (JKN) which is a concern to all parties. Multiplying programs that are commonly carried out with a "business as usual" scheme and increasing funding through financial assistance from the APBN / APBD cannot always be relied on in the long term, as evidenced during the 4 years of the JKN-KIS program from 2014 to 2018. Efforts to address the deficit through the provision of assistance from APBN funds does not effectively solve the problem. In addition, the diminishing availability of the State Budget is a threat to the sustainability of the JKN program.

This collaborative governance paradigm emphasizes the important role of actors outside the government in government affairs. It appears to accommodate the interests of the private sector and society that have not been involved in the public policy making process. On the other hand, it also brings about cost-sharing and knowledge exchange for the government. Furthermore, in accordance with the demands of the times, Emerson and Nabathi (2015) emphasize that collaborative initiators are not limited to being top-down but can be initiated by grassroots stakeholders or are bottom-up. Based on this concept, collaborative governance itself includes integration between various sectors that exist in a country. Ideally, the role of the state cannot be too dominant because the pattern of future development of public management demands that the state act as a partner that gives space to the public to become the main actor in the framework of participatory governance.

H2: Collaborative governance demands the Participation of Non-Governmental actors.

\section{Research Methodology}

\subsection{Data and Sample Selection}

The approach used in this study is post-positivism with qualitative and quantitative research methods. The qualitative approach is based on a participatory perspective, one component of which is collaboration. This method uses quantification of the answers of informants in the form of numbers. This research was limited to 13 institutions related to handling JKN. In essence, this research was conducted with the aim of describing how the suitability of the Collaborative Governance model that was formed in the efforts of the government 
and stakeholders to deal with the Joint issues related to the budget deficit in the JKN-KIS Program organized by BPJS Health.

Quantitative methods are used to answer the question of trends. The researchers used a questionnaire that was limited to 13 institutions related to locus in handling fraud in the JKN program. In-depth interview techniques were conducted with a number of informants who were used as sources to obtain data and information needed to analyze collaborative governance models in handling the JKN-KIS Program budget deficit. Data and information from informants also become a reference in analyzing the tendency of collaboration models in implementing Collaborative Governance in this case. Interviews conducted by researchers in this study use written interview guidelines that contain the scope of the list of questions to be asked with a decrease in the indicators to be examined from the concept of Collaborative Governance.

The researchers also obtained data through a Focus Group Discussion (FGD) involving several relevant stakeholders to see more about the processes and dynamics of collaborative governance built. Furthermore, a quantitative study through a questionnaire was developed by distributing questionnaires to 13 agencies that collaborated in handling JKN program including non-governmental institutions. In addition, the study of supporting documents is carried out by taking data and information from a number of books, research results, journals, magazines, websites and other reliable documentation sources on models and concepts of collaborative governance on the issue of budget deficits in health insurance.

\subsection{Basic Techniques for Determining Informants}

The basic technique of determining informants uses two methods, namely the purposive procedure and the snowball procedure (Bungin, 2007, p.107-108). First, a purposive procedure is carried out by determining the group of participants who become informants according to selected criteria that are relevant to the research problem. Data sources and informants is one of the most vital factors in any research. Therefore, researchers must be able to understand which data sources will be used in their research. There are two types of resources in this study, namely primary data sources and secondary data sources. Primary data sources are the first data sources obtained through interviews with predetermined respondents. While the secondary data source is the second data source used to help provide information or supplementary data as a comparison material (Bungin, 2013: 129).

To be able to meet the needs of data from primary and secondary data sources, researchers conducted indepth interviews with Social Security officials and councils regarding the implementation of collaborations and discussion forums on handling deficits in the JKN program. Researchers also conducted in-depth interviews with relevant actors at the Ministry of Health, BPJS Health, Association of Indonesian Hospitals, the Indonesian Medical Association, and several International Donor Institutions in their capacity and capability as other related stakeholders.

In addition to conducting in-depth interviews with the informants, the researchers also conducted literature studies, participated in Focused Group Discussions, distributed questionnaires and documented studies of the research objects. Furthermore, the documentation study was carried out by looking at regulations relating to collaboration as well as data and information that supported the research analysis.

\subsection{Data Presentation Techniques}

The research data is presented in the form of a frequency table in which there is a total score of the answers of each indicator in seeing the tendency of the collaboration model in handling JKN-KIS program budget deficits. The maximum value of each question is 5 and the minimum value of each question is 1 . The following score calculations were obtained:

\begin{tabular}{l|l|l|l} 
Maximum-Minimum Score & Score & Respondents & Total Score
\end{tabular}




\begin{tabular}{|c|c|c|c|}
\hline Maximum score & 5 & 15 & 75 \\
\hline Minimum score & 1 & 5 & 5 \\
\hline
\end{tabular}

Moreover, to find out the answer categories (good, enough, less) for each indicator of all questions submitted to the respondent, the researcher converted the answers into the percentage and categorization as follows:

\begin{tabular}{|c|c|}
\hline Answer score conversion & Category \\
\hline $25-50$ & less \\
\hline $51-75$ & enough \\
\hline $76-100$ & good \\
\hline
\end{tabular}

The categorization above is intended to provide an overview and understanding of how far or how many indicators are derived from the collaboration model developed by Ansell and Gash (2007) and Emerson and Nabatchi (2015) contained in the collaboration process on research issues. The form of the questions raised by the researcher was open in nature to allow the informant to convey answers to more than one choice.

\section{Results}

The results show that collaboration between government institutions tends to be difficult. This is due to the existence of authority boundaries and bureaucratic and political obstacles to the bureaucratic and political elites that have become the characteristics of public organizations in this matter in Indonesia. Government institutions actually seem to "spy on" each other between one another. There is not a bit of competition and the action of blaming each other when conflicts occur in an area that is less effectively carried out by other government institutions. There is a more dominant tendency that there are indications of "prestige" and ego sectoral traits that are very difficult to erode in public sector institutions. Sri Mulyani, in the RDP handling the JKN deficit said:

"I see from institutions to other institutions there is no good coordination. I observe one by one each government agency conveying different things to the public. So, the public sees that the government has not provided a real solution so that this is the root of public distrust or public accusation that the government is not present in this deficit problem. I appeal to the park friends from government institutions; DJSN, Ministry of Health, Ministry of Finance, BPJS Health do not elevate each sectoral ego, we as presidential aides must sit together and have one voice delivered to the public "(Discussion on JKN Deficit, May 2019).

The worst observation is the explicit effort to close opportunities for cooperation and avoid interaction and collaboration. This condition occurs in the external and internal environment in a system of contexts that influence each other in collaboration. The context system according to Emerson and Nabatchi (2015) is an environmental influence in the form of political, socioeconomic, cultural, and so on. On the other hand, Emerson and Nabatchi (2015) add that some efforts of initiating collaboration can occur naturally at the grassroots level (bottom-up) which appears as an effort to "stop" government decision makers. Specifically, Emerson and Nabatchi state that there are 3 types of formative of bottom-up collaboration namely:

(1) self-initiated;

(2) independently implemented; and

(3) externally directed. 


\section{Conclusion and Recommendations}

Based on the collaboration model formulated by Ansell and Gash (2007), the initial stage of collaboration is influenced by 3 main components, namely:

(1) the imbalance of power, knowledge, and resources that actors have in collaboration;

(2) incentives or coercion to collaborate; and

(3) the history of collaboration or the history of past conflicts experienced by actors in collaborative relationships.

Meanwhile, based on the model developed by Emerson and Nabatchi (2015), collaborative governance begins and develops in the context of a multi-layered system. The main elements of the system context are included in the 2 initial prerequisites. First, resource or service conditions, policy and legal frameworks, socio-economic and cultural characteristics, network characteristics, political dynamics and power relations, and the history of conflict. The context of this external system creates opportunities and constraints that affect the general parameters in which CGR begins operating. In addition, although CGR is influenced by the context of the system at the beginning and throughout its life cycle, the majority of CGR is formed with the expectation of also influencing this context through its actions. Hence, there is a kind of mutual influence from the system of external contexts on internal collaboration.

Second, there is leadership from actors who become initiators or promoters for collaboration. Leadership to initiate is needed to encourage early engagement among potential participants and create conditions for launching collaborative dynamics. These actors are called "drivers" who are present at various levels and at various levels of influence to begin the creation of collaboration. The basic reason for the initiation of forming a collaboration forum is because each organizer still manages and formulates solutions individually, partially and not well coordinated so that the impression of sectoral egos, interpretations of diverse legal bases causes overlapping policies and rules to be inevitable. On the other hand, the actors involved actually have shared awareness, knowledge, and motivation towards the existing problems.

Based on the results of the analysis outlined above, it can be concluded that government institutions have the same awareness and knowledge and balanced resources, but with that balance, each institution becomes reluctant to engage in collaborative efforts. In the development of governance today, non-governmental actors have become aware of the impact of public problems on individuals and their organizations so that problems such as the JKN deficit are also an interesting issue for Educational Institutions and other nongovernmental institutions. This is evident in some discussion forums as well as the fact that collaborative efforts with the agenda for discussing JKN deficits were initiated by private organizations and nongovernment organizations.

As we know, connectivity in the system of government continues to grow. In the era of industrial revolution 4.0 and the digitalization era currently, collaboration is the thing that brings civilization to life so that the existence of technology and connectivity makes collaboration an expensive item that must be owned by every organization, both private organizations and public organizations, in order to run the wheel of competition in the arena of industry and governance which are both innovative and competitive. This is very relevant to the needs of administrative and bureaucratic reform in Indonesia as a country that continues to make efforts to change its' system of governance and public services. The researchers believe that the practice of bottom-up collaboration in governance promises sustainable prospects for public programs and problems. Therefore, in the present and in the future, the scientific development of collaboration will still have a positive impact within public organizations. 


\section{References}

Agranoff, R. (2012). Collaborating to manage: A primer for the public sector. Georgetown University Press. https://doi.org/10.1093/jopart/mut036

Agrawal, A. (2003). Sustainable governance of common-pool resources: context, methods, and politics. Annual review of anthropology, 32(1), 243-262.https://doi.org/10.1146/annurev.anthro.32.061002.093112

Bardach, E. (1998). Getting agencies to work together: The practice and theory of managerial craftsmanship. Brookings Institution Press. DOI: 10.1016/S1096-7494(01)00047-2

O'Leary, R. (2018). Collaborative public management: the US perspective. In Handbook of American Public Administration. Edward Elgar Publishing. https://doi.org/10.2753/ATP1084-18063202010

Bryson, J. M., Crosby, B. C., \& Stone, M. M. (2006). The design and implementation of Cross- Sector collaborations: Propositions from the literature. Public administration review, 66, 44-55.https://doi.org/10.1111/j.15406210.2006.00665.x.

Creswell, J. W., \& Creswell, J. D. (2017). Research design: Qualitative, quantitative, and mixed methods approaches. Sage publications. https://doi.org/10.5539/elt.v12n5p4

Donahue, J. D., \& Zeckhauser, R. J. (2012). Collaborative governance: Private roles for public goals in turbulent times. Princeton University Press. https://doi.org/10.1080/10967494.2011.657120

Emerson, K., \& Gerlak, A. K. (2014). Adaptation in collaborative governance regimes. Environmental management, 54(4), 768-781.DOI 10.1007/s00267-014-0334-7

Emerson, K., Nabatchi, T., \& Balogh, S. (2012). An integrative framework for collaborative governance. Journal of public administration research and theory, 22(1), 1-29. https://doi.org/10.1093/jopart/mur011

Imperial, M. T. (2005). Using collaboration as a governance strategy: Lessons from six watershed management programs. Administration \& Society, 37(3), 281-320. https://doi.org/10.1177/0095399705276111

Linden, R. M. (2003). Working across boundaries: Making collaboration work in government and nonprofit organizations. John Wiley \& Sons. DOI: 10.1177/0899764004269429.

McGuire, M., \& Bevir, M. (2011). Network management. The SAGE handbook of governance, 436453.https://doi.org/10.1111/j.1540-6210.2006.00664.x.

O'Leary, Rosemary, and Lisa Blomgren Bingham. 2007. A Manager's Guide to Resolving Conflicts in Collaborative Networks. Washington, DC: IBM Center for the Business of Government. https://doi.org/10.1080/10967490601185799

Osbourne, D., \& Gaebler, T. (1983). Reinventing Government: How the Entrepreneurial Spirit is Transforming the Public Sector, 1992.https://doi.org/10.1080/00222216.1995.11949751

Osborne, S. P. (2010). The new public governance. Emerging Perspectives on the theory and practice of public governance, 1. https://doi.org/10.1080/14719030600853022

Ostrom, E. (1990). Governing the commons: The evolution of institutions for collective action. Cambridge university press. DOI: http://doi.org/10.18352/ijc.325

Rhodes, R. A. (1997). Understanding governance: Policy networks, governance, reflexivity and accountability. Open University. https://doi.org/10.1177/0170840607076586

Riley, J. M. (2002). Stakeholders in rural development: Critical collaboration in state-NGO partnerships. Sage. DOI: $10.1002 /$ bse. 1780

Ansell, C., \& Gash, A. (2008). Collaborative governance in theory and practice. Journal of public administration research and theory, 18(4), 543-571.https://doi.org/10.1093/jopart/mum032

Emerson, K., Nabatchi, T., \& Balogh, S. (2012). An integrative framework for collaborative governance. Journal of public administration research and theory, 22(1), 1-29. https://doi.org/10.1093/jopart/mur011

Emerson, K., \& Gerlak, A. K. (2014). Adaptation in collaborative governance regimes. Environmental management, 54(4), 768-781.https://doi.org/10.1080/15309576.2015.1031016

Emerson, K., Nabatchi, T., \& Balogh, S. (2012). An integrative framework for collaborative governance. Journal of public administration research and theory, 22(1), 1-29.DOI: https://doi.org/10.1093/jopart/mur011 